\title{
Comparison of shallow-water seston among biogenic habitats on tidal flats
}

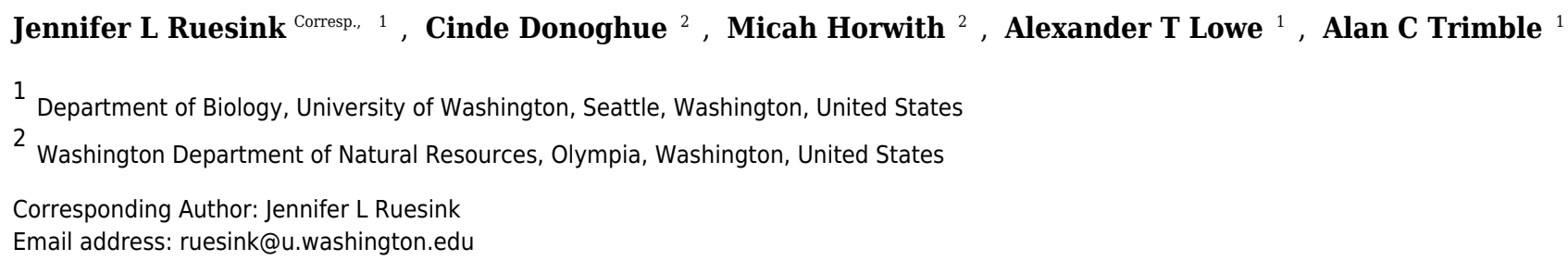

Aquatic structure-formers have the potential to establish mosaics of seston in shallow water if they modify the relative amounts of deposition (or filtration) and resuspension of particles. By sampling surface water adjacent to Lagrangian drifters traveling 0.1 to $2 \mathrm{~m}$ above the bottom, we tested the modification of seston in water masses flowing over two biogenic marine species (native eelgrass, Zostera marina; introduced oysters, Crassostrea gigas) in comparison to unstructured tidal flats. Water properties were examined at five intertidal sites in Washington State, USA, each with 27 drifts (three drifts at different stages of the tidal cycle in each of three patches of three habitat types; drift distance 116 m (109SD), duration 24 min (15SD)). At the initiation of each drift, habitat differences in water properties were already apparent: chlorophyll-a and total suspended solid (TSS) concentrations were greater in structured habitats than bare, and TSS was also inversely related to water depth. Water flowed more slowly across eelgrass than other habitat types. As water flowed across each habitat type, TSS generally increased, especially in shallow water, but without habitat differences; chlorophyll-a in these surface-water samples showed no consistent change during drifts. At higher TSS concentrations, quality in terms of organic content declined, and this relationship was not habitat-specific. However, quality in terms of chlorophyll-a concentration increased with TSS, as well as being greater in water over eelgrass than over other habitat types. These results support widespread mobilization of seston in shallow water ebbing or flooding across Washington State's tidal flats, especially as water passes into patches of biogenic species. 
1 Comparison of shallow-water seston among biogenic habitats on tidal flats

3 Ruesink $\mathrm{JL}^{1}$, Donoghue $\mathrm{CR}^{2}$, Horwith $\mathrm{MJ}^{2}$, Lowe $\mathrm{AT}^{1}$, Trimble $\mathrm{AC}^{1}$

4

$5 \quad{ }^{1}$ Department of Biology, University of Washington, Box 351800, Seattle, Washington, USA

$6{ }^{2}$ Washington Department of Natural Resources, Aquatic Resources Division, 1111 Washington St

7 SE, Olympia, Washington 98504, USA

8

9 Author for correspondence: JL Ruesink, Email: ruesink@uw.edu, Tel: 01-206-543-7095

10

11 Running head: Shallow-water seston on tidal flats 


\section{ABSTRACT}

13 Aquatic structure-formers have the potential to establish mosaics of seston in shallow water if

14 they modify the relative amounts of deposition (or filtration) and resuspension of particles. By sampling surface water adjacent to Lagrangian drifters traveling 0.1 to $2 \mathrm{~m}$ above the bottom, we tested the modification of seston in water masses flowing over two biogenic marine species (native eelgrass, Zostera marina; introduced oysters, Crassostrea gigas) in comparison to unstructured tidal flats. Water properties were examined at five intertidal sites in Washington State, USA, each with 27 drifts (three drifts at different stages of the tidal cycle in each of three patches of three habitat types; drift distance $116 \mathrm{~m}$ (109SD), duration $24 \mathrm{~min}$ (15SD)). At the initiation of each drift, habitat differences in water properties were already apparent: chlorophyll$a$ and total suspended solid (TSS) concentrations were greater in structured habitats than bare, and TSS was also inversely related to water depth. Water flowed more slowly across eelgrass than other habitat types. As water flowed across each habitat type, TSS generally increased, especially in shallow water, but without habitat differences; chlorophyll- $a$ in these surface-water samples showed no consistent change during drifts. At higher TSS concentrations, quality in terms of organic content declined, and this relationship was not habitat-specific. However, quality in terms of chlorophyll- $a$ concentration increased with TSS, as well as being greater in water over eelgrass than over other habitat types. These results support widespread mobilization of seston in shallow water ebbing or flooding across Washington State's tidal flats, especially as water passes into patches of biogenic species.

\section{INTRODUCTION}


36 Intertidal organisms, in addition to spending time in both water and air, experience short-term

37 variation because coastal water fluctuates in such properties as dissolved gas concentrations

38 (Duarte et al. 2013) and particle loads (Ralph et al. 2007). The amount and composition of

suspended particulate matter, termed seston, has important implications for the productivity of macrophytes via light limitation (de Boer 2007) and for benthic suspension feeders via food resources (e.g. Kang et al. 2003). Quantifying how biogenic species influence the mobilization and removal of particles improves understanding of the feedbacks governing local heterogeneity in water properties (Widdows et al. 2000, de Boer 2007). In this study, we track water properties across tidal flats and compare unstructured habitat to two dominant structure-forming species: eelgrass (Zostera marina) and oysters (Crassostrea gigas).

These two species are expected to modify water properties in different ways. As suspension-feeders, oysters remove particles, and water passing across oyster beds typically declines in chlorophyll concentration (Grizzle et al. 2006, 2008, Grangere et al. 2010, Plutchak et al. 2010, Wheat and Ruesink 2013). Away from the footprint of oysters, mixing and compensatory phytoplankton dynamics obscure this trophic effect (Dame and Libes 1993, Plutchak et al. 2010). Seagrass influences seston predominantly as a side effect of altering water motion, since more rapid flow or turbulence can lift and transport larger, denser particles (Widdows et al. 2008, Wilkie et al. 2012). Empirically, seagrass beds buffer against water motion and accumulate fine particles (Fonseca et al. 1982, Kenworthy et al. 1982). However, effects on flow velocity and turbulence within and around structure are sensitive to a variety of parameters that naturally vary in the field, including the fraction of the water column occupied by structure (Moore 2004, Hasegawa et al. 2008, Luhar et al. 2008), and the density and flexibility of structural elements (Adhitya et al. 2014, Houser et al. 2015). Seagrass contributes tall, flexible structure, whereas oysters are stiff and typically shorter (although reefs can build up from gregarious settlement and particle trapping; Walles et al. 2015). Bivalves such as hard clams can 
61 intensify erosional processes and accordingly augment seston, even while drawing down

62 phytoplankton biomass overall (Porter et al. 2013). Similarly, benthic animals that bioturbate

63 sediment or graze biofilms are associated with increased erodability of sediments (Widdows et al.

64 2000, Guizien et al 2014). However, biogenic species might block the sediment surface and

65 therefore reduce the surface area subject to resuspension. Dense seagrass in tidally dominated

66 flow regimes is expected to slow laminar flow or divert flow away from sediment through

67 skimming flow (Koch and Gust 1999, de Boer 2007), whereas oyster reefs may increase turbulent

68 flow with ancillary effects on particle transport (Colden et al. 2016).

On intertidal flats, the water transiting across a particular patch can vary dramatically in

70 depth and motion through the tidal cycle. The consequences for water column seston are,

71 however, difficult to predict because of covarying factors that may act in opposite directions.

72 Specifically, shallow water near low tide may allow orbital motion of small waves to resuspend

73 sediment, a process that no longer interacts with the bottom as depth increases (Green 2011). Yet

74 current speed could be increasing from slack low tide to mid-tide, increasing resuspension even

75 as depth increases (Widdows et al. 2000, Orvain et al. 2014). At the same time, given evidence of

76 vertical gradients of some particle types in shallow water (Judge et al. 1993, Guizien et al. 2014),

77 benthic effects on water sampled at the surface may decline as depth increases simply due to

78 distance from the bottom. As water depth increases, seagrass occupies a smaller fraction of the

79 water column and its effects on surface water decline (Koch 2001, Luhar et al. 2008). Similarly,

80 deeper water depths dilute the effects of suspension-feeders on a per-volume basis. Thus surface

81 water properties might be expected to become more homogeneous across a mosaic of habitat

82 types as water depth increases; that is, depth $\times$ habitat interaction.

To empirically demonstrate the spatio-temporal heterogeneity of water properties on tidal

84 flats, we sampled surface water over different habitat types, at multiple water depths experienced

85 through the tidal cycle. We expected that water velocity would increase from low to mid-tide 
86 depths and that eelgrass would baffle currents. We expected water depth $\times$ habitat interactions for

87 seston in which structured habitats influenced water properties at shallower depths, but

88 heterogeneity was reduced among habitat types as surface water was farther from the sediment.

89 For water properties of total suspended solids and chlorophyll- $a$, we evaluated both the static

90 differences among habitat types based on point samples and the dynamic changes as water

91 transited over bare tidal flat, eelgrass, or oysters.

\section{METHODS}

\section{Study sites}

95 The study took place at five low intertidal sites in Washington State, where eelgrass (Zostera 96 marina), oysters (Crassostrea gigas), and unstructured bare mudflat co-occur near mean lower

97 low water. The sites occupied distinct bays: Willapa Bay on the outer coast $\left(46.5^{\circ} \mathrm{N}, 124.0^{\circ} \mathrm{W}\right)$, 98 Samish Bay in north Puget Sound (48.6 $\left.{ }^{\circ} \mathrm{N}, 122.5^{\circ} \mathrm{W}\right)$, Case Inlet in south Puget Sound $\left(47.3^{\circ} \mathrm{N}\right.$, $\left.99122.8^{\circ} \mathrm{W}\right)$, Port Gamble $\left(47.8^{\circ} \mathrm{N}, 122.6^{\circ} \mathrm{W}\right)$ and Dabob Bay $\left(47.8^{\circ} \mathrm{N}, 122.8^{\circ} \mathrm{W}\right)$ in Hood Canal, 100 which is a natural fjord connected to Puget Sound (Fig. 1A). These tidal flats are exposed to air 101 on extreme low tides and experience a mean tidal range of $2.1 \mathrm{~m}$ (Samish Bay, Willapa Bay) to $1023.1 \mathrm{~m}$ (Case Inlet). Sediment type spans a range of sandy to muddy conditions (1-4\% organic content, Richardson et al. 2008, Yang et al. 2013). The bays were selected to be representative of

104 the diversity of eelgrass and oyster habitats in Washington State, so site was considered a random 105 effect in all analyses. Recruitment of C. gigas, which is non-native, rarely occurs in Samish Bay 106 and Case Inlet, so at these sites in particular, habitat patches of oysters were the product of 107 aquaculture activities. Although these oysters can form vertical reefs, we focused on places where 108 they occurred in clusters over large areas, consistent with the dimensions of other habitat patches. 109 Each site was sampled over four days of spring tides in 2014 (Port Gamble 14-17 May, Case 2611029 May, Dabob 11-15 Jun, Willapa 25-28 Jun, Samish 10-14 Jul). 


\section{Study design}

113 The study design was nested, with measurements at three subsites in each of five sites. Each

114 subsite consisted of patches of each of three habitats (bare, eelgrass, oysters), for a total of nine

115 habitat patches per site. Thus, habitat type had three true replicates (i.e., distinct, interspersed) in

116 each of the five sites. A patch had to exceed $20 \mathrm{~m}$ in its minimum dimension in order to be

117 selected for study, and most were an order of magnitude larger than this. Each patch was sampled

118 three times at different water levels, including upstream (initial) and downstream (final) paired

119 samples. Overall, the design emphasized habitat type and water level as main effects. Across all

120 five sites, we sampled 45 patches (evenly divided among bare, eelgrass, and oyster), with each

121 patch sampled upstream and downstream at three water levels during the tidal cycle.

\section{Benthic sampling}

124 Each of the 45 patches was surveyed at low tide, by placing $10\left(0.25 \mathrm{~m}^{2}\right)$ quadrats at random intervals along a 50-m transect. In each quadrat in oyster habitat, we counted all live oysters and measured the first 10 for shell height (nearest $0.5 \mathrm{~cm}$ ). In each quadrat in eelgrass, we counted eelgrass shoots and collected above-ground material of eelgrass. Eelgrass across these sites shows several ecotypic growth forms: smallest in Case Inlet ( $0.2 \mathrm{~m}$ average shoot length), intermediate in Port Gamble and Dabob Bay (0.3-0.6 m), and longest in Willapa Bay and Samish Bay (0.8-1.2 m). In quadrats in all habitats, we assessed shell cover and collected any macrophytes to assess biomass. Above-ground material of eelgrass and other macrophytes was dried separately $\left(60^{\circ} \mathrm{C}\right.$ for 5 days) and weighed. Biomass of oysters was estimated from density and size-frequency based on the length-weight relationships of Kobayashi et al. (2007), first at the quadrat level and

134 then calculated per patch. Each of the 45 patches was described by the mean ( $\mathrm{n}=10$ quadrats) and 
135 variation in above-ground biomass of primary producers and suspension-feeding oysters (Fig. 1B, 136 C).

138 Water sampling

139 To assess changes in water properties across patches, we tracked parcels of water with neutrally 140 buoyant Lagrangian drifters consisting of a PVC frame at the surface of the water and a circular 141 skirt, $80 \mathrm{~cm}$ in diameter and extending $10 \mathrm{~cm}$ into the water (Fig. 2, also used in Wheat and 142 Ruesink 2013). This approach enables sampling the same water over time, clarifying what was 143 "upstream" and "downstream" at any particular time, and accounting for potentially variable 144 initial conditions. We restricted our sampling to periods of light winds, since wind can decouple 145 the drifter from strictly tracking the water (pers. obs.). These light-wind conditions limited the 146 development of surface waves, and water transport during sampling was driven by tidal currents. 147 Eelgrass, oyster and unstructured tidal flat habitats were sampled concurrently. A waterproofed 148 GPS (Garmin GEKO) was secured at the center of each drifter to ride on the water surface. Three 149 drifts were carried out for each of the 45 habitat patches ( 27 drifts per site), spanning a range of 150 water depths as depth changed during the tidal cycle. Water depth ranged from $0.1 \mathrm{~m}$ to $\sim 2 \mathrm{~m}$ 151 (94\% of drifts occurred at water depths $<2 \mathrm{~m})$, which represented about half of the tidal amplitude during the sampling periods of spring tides. Most (85\%) of drifts occurred on ebb 153 tides. Drifts generally lasted half an hour, but duration was constrained by patch size and water 154 velocity (Fig. 3). At the beginning of a drift, starting near a patch edge where water was flowing 155 in to the patch, a person in a kayak collected water samples at $\sim 0.3 \mathrm{~m}$ below the surface (or less 156 in shallower water). Effort was made to collect water samples as close to the drifter as possible without disturbing its motion or the bottom. Water depth was evaluated by holding the paddle

158 vertically and checking the water level at $0.1 \mathrm{~m}$ increments. As the drifter exited the patch, water 159 samples were collected again. Each water sample collection consisted of three $300 \mathrm{ml}$ Nalgene 
160 bottles for pigment analysis and one 1-L bottle for total suspended solids (TSS). All bottles were 161 kept cold and dark and were filtered through $47 \mathrm{~mm}$ glass fiber filters $(\mathrm{GF} / \mathrm{F}, 0.7 \mu \mathrm{m}$ pore size)

162 within three hours of collection. Samples for pigment analysis were placed in $10 \mathrm{ml}$ of $90 \%$

$163(\mathrm{~W} / \mathrm{V})$ acetone and kept frozen and dark. At the end of the field season, these samples were

164 measured for chlorophyll- $a(\mathrm{Chl})$ via standard acidification procedure on a Turner Designs AU-

16510 fluorometer (Welschmeyer 1994). Samples for TSS were filtered through pre-weighed filters,

166 dried to determine mass of material, and combusted at $500^{\circ} \mathrm{C}$ for three hours to determine organic

167 content by loss-on-ignition. A few of these samples dried incompletely, generating large values

168 for TSS (including some water) and for organic content (also including some water), and we

169 censored nine values (eight drifts) with proportion organic $<0$ or $>0.5$. The time of collection of

170 initial and final samples was recorded by the kayaker, which enabled later extraction of geo-

171 positions from GPS units recording at $10 \mathrm{~s}$ intervals. The absolute distance between initial and

172 final positions (in m, accounting for non-parallel longitude), divided by the duration of the drift, 173 defined drift velocity.

\section{Data analysis}

176 Five water properties were tested for depth and habitat differences. Two of these water properties

177 were TSS and Chl collected at the initiation of each drift. Two were the change in TSS and Chl

178 during each drift, using samples collected initially and finally in calculations of

$179 \ln \left(\mathrm{TSS}_{\text {final }} / \mathrm{TSS}_{\text {initial }}\right)$ and $\ln \left(\mathrm{Chl}_{\text {final }} / \mathrm{Chl}_{\text {initial }}\right)$. The fifth response variable was drift velocity. Each of 180 these response variables was used in a linear mixed effects model, with fixed effects of habitat

181 type, $\ln ($ water depth), and their interaction, and random effects of site and subsite in site. Three

182 Chl samples collected simultaneously were averaged prior to analysis. The study design was

183 unbalanced for any test of whether patterns differed between ebb and flood tides, or as a function 
184 of water residence time in a habitat patch. In exploratory analyses, these correlates explained

185 little of the residual variation and were not considered further.

186 Quality of seston was evaluated through relationships of organic content and Chl to TSS.

187 In these analyses, all samples from both initial and final collections for each drift were used.

188 Response variables of $\ln (\mathrm{Chl})$ and $\ln$ (proportion organic) were used in linear mixed effects

189 models, with fixed effects of habitat type, $\ln (\mathrm{TSS})$, and their interaction, and random effects of

190 site and subsite in site. In all these analyses, any significant habitat effect was followed up by

191 planned contrasts testing bare vs. eelgrass, and bare vs. oyster.

192 Residuals in all analyses were examined visually for normality, and TSS and Chl required

193 ln-transformation. Following Zuur et al. (2009), we tested for optimal random effects structure,

194 which included random intercepts in all models. Statistical significance of predictors was set at

$195 \alpha=0.05$. However, when linear mixed effects models generate P-values near the border of

196 significance, this provides weak evidence of their importance (Zuur et al. 2009). Linear mixed

197 effects models were re-run with only significant factors in order to find coefficients for best-fit

198 lines in visual display of data. Linear mixed effects analyses were carried out with nlme (Pinheiro 199 et al. 2016) in R (R Core Team 2015). Characteristics of each of the 135 drifts have been archived 200 (Ruesink 2018).

RESULTS

203 Benthic composition of patches

204 Eelgrass patches contained $38-120 \mathrm{gDW} \mathrm{m}^{-2}$ in above-ground biomass of eelgrass (Fig. 1B), with

205 an overall moderate coefficient of variation $(\mathrm{CV}=\mathrm{SD} /$ mean $=0.32, \mathrm{n}=15$ patches $)$. Oyster

206 patches were more variable in estimated live oyster biomass $\left(10-270 \mathrm{gDW} \mathrm{m}{ }^{-2}, \mathrm{CV}=0.84\right.$, Fig.

207 1C) and ranged from 8 to $97 \%$ shell cover (mean $49 \%, C V=0.53, n=15$, also positively 
208

correlated with live oyster biomass, $r=0.52$ ). For both biogenic species, these densities are categorized as functionally dense, since fluid dynamics for sparse structure typifies cover $<10 \%$ (Bouma et al. 2007). Other primary producers, in particular macroalgae, were present in some patches, averaging $2 \mathrm{gDW} \mathrm{m}^{-2}$ in bare and eelgrass patches, but $20 \mathrm{gDW} \mathrm{m}^{-2}$ in oyster patches, possibly reflecting the availability of hard surface for anchoring.

\section{Water properties at the initiation of drifts}

Based on initial samples from each drift, the analysis of TSS revealed significant main effects of habitat and water depth, while $\mathrm{Chl}$ responded only to habitat type (Table 1). Higher concentrations of TSS and Chl were present in both biogenic habitats than over bare tidal flat, although the oyster-bare comparisons had P-values closer to $\alpha=0.05$ that should be interpreted cautiously in linear mixed effects models. TSS declined as water depth increased, but Chl did not (Fig. 4, Table 1). The depth-related differences for TSS were in keeping with predictions of increased resuspension in shallow water, but the lack of depth $\times$ habitat interactions meant that the heterogeneity in surface water properties across habitat types was not muted as water level rose.

\section{Water properties during drifts}

Based on initial and final samples from each drift, the analysis of $\ln \left(\mathrm{TSS}_{\text {final }} / \mathrm{TSS}_{\text {initial }}\right)$ revealed a significant effect of water depth, but no factors were significant for $\ln \left(\mathrm{Ch}_{\text {final }} / \mathrm{Ch}_{\text {initial }}\right)$ (Table 1). Specifically, TSS continued to increase during drifts in shallow water but not when more water covered these patches (Fig. 5). No habitat differences or habitat $\times$ depth interactions emerged in analyses of changes in water properties during drifts (Table 1). Accordingly, distance to the 
231 sediment was important for the dynamics of TSS, but neither eelgrass nor oysters cleared the 232 water of particles, regardless of water depth.

\section{Water velocity}

235 Drift velocity showed main effects of habitat type and water depth but no interaction (Table 1).

236 Dropping one fast outlier, velocity averaged $0.128 \mathrm{~m} \mathrm{~s}^{-1}(\operatorname{SD} 0.126, \mathrm{n}=43)$ across bare tidal flats, $2370.115 \mathrm{~m} \mathrm{~s}^{-1}\left(\mathrm{SD} 0.114, \mathrm{n}=43\right.$ ) over oysters, and $0.085 \mathrm{~m} \mathrm{~s}^{-1}$ (SD 0.096, $\left.\mathrm{n}=44\right)$ over eelgrass (Fig. 238 3). Drifts over eelgrass were $33 \%$ slower relative to bare tidal flats, but this effect did not depend 239 on water depth. Drifts increased in velocity when more water was over habitat patches, consistent 240 with currents through the tidal cycle (Fig. 6). Across all drifts, $62 \%$ were slower than $0.1 \mathrm{~m} \mathrm{~s}^{-1}$, 241 and the 49 that were faster than this included all 27 drifts in Samish Bay (Fig. 3).

\section{Seston quality}

244 Proportion organic was significantly related to TSS, whereas Chl additionally differed by habitat 245 type. Chl was positively related to TSS, rising from 4 to $6 \mu \mathrm{g} / \mathrm{L}$ across a range of TSS that varied 246 by two orders of magnitude (5 to $500 \mathrm{mg} / \mathrm{L}$; Fig. 7, Table 2). Across this same range of TSS, 247 organic content declined, shifting from $30 \%$ to $10 \%$ (Fig. 7). Seston characteristics differed by 248 habitat for Chl, which was higher for a given amount of TSS in eelgrass relative to bare tidal flat 249 (Table 2).

\section{DISCUSSION}

252 In our measurements of material carried by surface water across tidal flats, TSS was inversely 253 related to water depth and tended to increase further during transit in shallow water (Fig. 4, 5).

254 Such increases in particle loads in water flowing across tidal flats have been documented 
255 previously in the field (Guizien et al. 2014), and resuspension often governs shallow water

256 properties, in terms of both the amount and characteristics of seston (Gacia and Duarte 2001,

257 Newell and Koch 2004). Resuspension increases with current speed (up to a point) in flume

258 studies, while the water velocity able to lift particles is contingent on bottom properties

259 (Widdows et al. 2000, Ovain et al. 2014). Thus, TSS in our surface water samples was affected

260 more by vertical water motion (depth or distance to sediment) than by horizontal water motion

261 (current speed), which acted in an opposite direction to observed results. That is, as more water

262 covered the tidal flat, it traveled faster (Fig. 6) and carried less TSS at the surface (Fig. 4, 5).

263 Contrary to expectations, no water depth $\times$ habitat interactions were apparent in TSS and Chl.

264 Regardless of depth, highest TSS and Chl concentrations were observed over eelgrass, where

265 reduced water velocity was expected to lead to particle settling (Fig. 4). We found little evidence

266 of top-down control by oysters, given that change in Chl over oysters was similar to that in other

267 habitat types (Fig. 5).

268 Both biogenic species acted as seston-mobilizers based on comparisons of initial drift

269 values (Fig. 4), but this effect was not apparent for changes during drifts (Fig. 5, Table 1).

270 Specifically, in initial samples, surface water over eelgrass and oysters contained twice the

271 concentration of TSS relative to bare: 38.0 (7.9 SE), 36.9 (9.8 SE), and $19.3(1.5 \mathrm{SE}) \mathrm{mg} \mathrm{L}^{-1}$,

272 respectively. This habitat-specificity in initial values was also apparent in Chl: 6.4 (0.8 SE), 4.7

273 (0.6 SE), and $3.7(0.3 \mathrm{SE}) \mu \mathrm{g} \mathrm{\textrm {L } ^ { - 1 }}$. The finding that biogenic habitats did not further influence

274 seston differentially with respect to bare suggests that the mosaic of intertidal water properties is

275 established at patch borders, for instance because erosional processes tend to be enhanced at

276 leading edges of structured habitats (Adams et al. 2016). Factors expected to result in build-up of

277 effects during drifts, such as suspension feeder activity, may not differ among habitats as 
278

279 Peterson and Black 1987).

280

281

282

283

284

285

286

287

288

289

290

291

292

293

294

295

296

297

298

299

300

301

302

expected from oysters alone, given that we did not sample for infaunal suspension-feeders (i.e.

Despite the absence of predicted water depth $\times$ habitat effects, differential responses to

water depth for surface TSS and Chl can help infer causes of spatio-temporal heterogeneity over

these tidal flats. TSS was inversely related to depth in terms of both concentration and change

during drifts, but the amount and dynamics of Chl were unrelated to water depth (Figs. 4, 5, Table

1). Evidently, resuspension of material on these tidal flats predominantly mobilized non-

photosynthetic material, thus augmenting TSS without changing Chl. This explanation is

supported by the negative relationship between proportion organic and TSS in analyses of seston

quality (Fig. 7). Although Chl was positively related to TSS, the slope of this relationship was

small, given ca. 50\% increase in Chl over a range of TSS spanning two orders of magnitude (Fig.

7), and insufficient to drive identical depth-related patterns for particulates as a whole and for

Chl. In other studies, benthic microalgae were found to be lifted into the water column under

conditions of lower water energy than can mobilize mineral particles (Orvain et al. 2014) and to

distribute without much gradient in the water column (Guizien et al. 2014). Due to evidence in

our study that primarily inorganic particles were resuspended in shallow water, we interpret this

to mean that benthic microalgae were already mobilized under the full range of drift velocities

and depths, or that populations of benthic microalgae were not well developed on these tidal flats.

In retrospect, a large gap in our study is that we do not have coupled measurements of

sediment properties for all drift locations. It is reasonable to expect that eelgrass and oysters

could influence sediment properties, and that a source of seston could be biodeposits in the case

of oysters and locally-produced organic matter in eelgrass. However, in some past work we have

found no consistent differences in the sediment of these habitat types relative to bare tidal flat

(Richardson et al. 2008). In the present case, we cannot test how much of the variation in seston

among drifts is a function of the sediment type over which the water passes, therefore precluding 
303 an assessment of this potential mechanism underlying the heterogeneity in shallow water

304 properties that we documented.

305 Attenuation of water movement by seagrass has been observed in many field and lab

306 studies and is largely dependent on the current speed (Fonseca et al. 1982), driver of water

307 motion (e.g. wind vs. tide, Koch and Gust (1999)), habitat configuration (patch vs. continuous,

308 Worcester 1995), and seagrass density and shoot length (Moore 2004, Hasegawa et al. 2008). In

309 our study, water velocity was reduced over eelgrass relative to other habitat types (Fig. 6, Table

310 1). Thus, all combinations of canopy height and water depth represented conditions suitable for

311 modifying surface flow. It may be necessary to include drifts at still deeper water depths

312 associated with extreme high tides to see evidence of any habitat $\times$ depth interaction, which

313 should emerge because flow reduction extends only to a factor of two of canopy height (Luhar et

314 al. 2008).

315 Why, then, did this slower flow not lead to deposition of particles and a clearing of the

316 water column in eelgrass? Instead, we speculate that eelgrass on these tidal flats may increase

317 water turbulence and/or surface area hosting fragile microalgal epibionts. Seagrass biomass tends

318 to be concentrated off-bottom, and the near-bottom material is gathered into leaf sheaths.

319 Accordingly, reduced drag may enable faster near-bottom flow that fosters erosional rather than

320 depositional processes (Madsen et al. 2001, Koch et al. 2006). Key tests in flumes have been

321 carried out on small, dense morphotypes of eelgrass (e.g., 1000 shoots $\mathrm{m}^{-2}$ of $\sim 20 \mathrm{~cm}$ length;

322 Fonseca and Koehl 2006), whereas most eelgrass morphotypes found in Washington State are

323 larger, sparser, and therefore more likely to result in resuspension. The second possibility is

324 contribution to seston from the microalgae and trapped sediments on the surface area of the

325 eelgrass leaves. This layer of fine fuzz can represent almost as much dry mass as the eelgrass

326 itself during summer months (Nelson and Waaland 1997, Ruesink 2016). Mobilization of

327 epiphytes into the water column could underlie the higher quality (as Chl) of seston in eelgrass 
328 relative to other habitats in our study (Fig. 7). Specifically, $50 \mathrm{mg} \mathrm{L}^{-1}$ of TSS is associated with 329 about $5 \mu \mathrm{g} \mathrm{L}^{-1}$ of Chl (Fig. 7), but $50 \mathrm{mg}$ of material scraped from eelgrass leaves contains 100

$330 \mu \mathrm{g}$ of Chl, yet a moderate organic content (13\%, Ruesink 2018). Overall, suspended materials in

331 water moving through eelgrass may depend on morphologically-mediated differences in bottom

332 turbulence resuspending benthic particles or picking up materials from the large surface area of 333 eelgrass leaves.

334 One other issue regarding water velocity is worth noting here, which is the rapid flow in 335 Samish Bay (Fig. 3), where the bathymetry has a shallow grade. Eelgrass in Washington State 336 exhibits two spatial configurations: flats (areas with extensive broad shallows such as river deltas 337 and pocket beaches) and fringes (areas with linear eelgrass distribution due to steep bathymetry; 338 Berry et al. 2003). Samish Bay was our only site where sampling overlapped eelgrass flats.

339 There, the bathymetry was conducive to both extensive eelgrass and rapid flow, resulting in drift 340 durations similar to other sites. Overall, the flat vs. fringe dichotomy needs further examination 341 for the engineering of water properties by biogenic species. In this study, with one "flat" and four 342 "fringes", it was necessary to consider site a random effect.

343 Many studies of water properties directly over shellfish beds have documented 344 measurable depletion of water column resources (Grizzle et al. 2006, 2008, Grangere et al. 2010, 345 Plutchak et al. 2010, Wheat and Ruesink 2013). Downstream concentrations of Chl are typically 346 lower than upstream concentrations, but not as different as would be expected from scaling up 347 filtration rates measured in the laboratory (Grizzle et al. 2008, Wheat and Ruesink 2013). Here 348 we found little evidence of oyster filtration reducing Chl or particle loads above patches (Table 1). This weak effect may be due to overall low oyster biomass, that is, averaging $<100 \mathrm{gDW} \mathrm{m}^{-2}$

350 relative to $400 \mathrm{gDW} \mathrm{m}^{-2}$ where drawdown has been documented in Washington State (Wheat and 351 Ruesink 2013). Also, our baseline condition of "bare" tidal flats contained unknown numbers of 
352 infaunal suspension-feeders. Because seston did not decline during drifts in any habitat type, our

353 data point towards resuspension as a factor that may complicate assessments of the filtration

354 capacity of shellfish. Other researchers have noted rapid variation in processing speed in response

355 to food quality and quantity (Barillé et al. 1997) and filtration failing to scale with abundance due

356 to the collective consequence of reef structure (Colden et al. 2016). The accumulation of

357 empirical evidence regarding filtration as an ecosystem service is essential to understanding the

358 conditions under which bivalves can improve water quality, and by how much.

\section{CONCLUSIONS}

361 Ecological interest in resuspension processes in shallow water has been motivated by

362 understanding food web linkages and subsidies among habitats. Sediment resuspension has a

363 number of potential ecological feedbacks to the biogenic species considered in this study.

364 Resuspension provides a potential benefit to suspension-feeders as they may use benthic

365 microalgae or other organic particles in their diet (Kang et al. 2003, Herman et al. 2000, van

366 Oevelen et al. 2006). In contrast, for seagrass, resuspension contributes to light attenuation and

367 provides a mechanism whereby alternative stable states can occur, when seagrass clears its own

368 water (Ralph et al. 2007, De Boer 2007), which was not the case in our study. Our empirical

369 examination of seston in surface water passing across tidal flats revealed spatial heterogeneity

370 that mapped on to habitat mosaics and shifted during the tidal cycle. Potential food resources

371 were elevated in eelgrass, as has been demonstrated in other species of seagrass as well (Judge et

372 al. 1983, LeBreton et al. 2011). We worked at particularly low water levels in a dynamic tidal

373 environment, which may help explain why resuspension appeared as a primary driver of seston.

374 The habitat-specific mosaic that we documented may be a feature of summer sampling, given

375 seasonally high biomass of eelgrass, although also providing a best-case temperature scenario for

376 oysters to feed (Ren and Ross 2001). The relative rates of deposition, filtration, and resuspension 
377 deserve further scrutiny across sediment types, more extreme water depths, and morphologies 378 and epiphyte loads of eelgrass, which could be additional factors involved in the spatial transfer 379 of resources in coastal environments.

\section{Acknowledgements}

382 We appreciate access to field sites from Taylor Shellfish and Port Gamble Sk'lallam Tribe. 383 Michael Hannam, Collin Gross, Joy Polston-Barnes, and Dolores Sare contributed to field work.

\section{References}

Adams, M.P., Hovey, R.K., Hipsey, M.R., Bruce, L.C., Ghisalberti, M., Lowe, R.J., Gruber, R.K., Ruiz-Montoya, L., Maxwell, P.S., Callaghan, D.P., Kendrick, G.A., O’Brien, K.R., 2016. Feedback between sediment and light for seagrass: where is it important? Limnology and Oceanography 61, 1937-1955.

Adhitya, A., Bouma, T.J., Folkard, A.M., van Katwijk, M.M., Callaghan, D., de Longh, H.H., Herman, P.M.J., 2014. Comparison of the influence of patch-scale and meadow-scale characteristics on flow within seagrass meadows: a flume study. Marine Ecology Progress Series 516, 49-59.

Barillé, L., Prou, J., Heral, M., Razet, D., 1997. Effects of high natural seston concentrations on the feeding, selection, and absorption of the oyster Crassostrea gigas (Thunberg). Journal of Experimental Marine Biology and Ecology 212, 149-172.

Barton, K., 2015. Package ‘MuMIn’ cran.r-project.org/web/packages/MuMIn/MuMIn.pdf Berry, H.D., Sewell, A.T., Wyllie-Echeverria, S., Reeves, B.R., Mumford, T.F., Skalski, J.R., Zimmerman, R.C., Archer, J., 2003. Puget Sound Submerged Vegetation Monitoring Project: 2000-2002 Monitoring Report. Nearshore Habitat Program, Washington State Department of 
402 Bouma, T.J., van Duren, L.A., Temmerman, S., Claverie, T., Blanco-Garcia, A., Ysebaert, T., 403 Herman, P.M.J., 2007. Spatial flow and sedimentation patterns within patches of epibenthic 404 structures: Combining field, flume and modelling experiments. Continental Shelf Research $405 \quad 27,1020-1045$.

406 Burnham, K.P., Anderson, D.R., 2002. Model selection and multimodel inference: a practical 407 information-theoretic approach. Springer, New York, USA

408 Colden, A.M., Fall, K.A., Cartwright, G.M., Friedrichs, C.T., 2016. Sediment suspension and 409 deposition across restored oyster reefs of varying orientation to flow: implications for $410 \quad$ restoration. Estuaries and Coasts 39, 1435-1448.

411 De Boer, W.F., 2007. Seagrass-sediment interactions, positive feedbacks and critical thresholds 412 for occurrence: a review. Hydrobiologia 591, 5-24.

413 Duarte, C.M., Hendriks, I.E., Moore, T.S., Olsen, Y.S., Steckbauer, A., Ramajo, L., Carstensen, J., 414 Trotter, J.A., McCulloch, M., 2013. Is ocean acidification an open-ocean syndrome?

415 Understanding anthropogenic impacts on seawater $\mathrm{pH}$. Estuaries and Coasts 36, 221-236. 416 Fonseca, M.S., Fisher, J.S., Zieman, J.C., Thayer, G.W., 1982. Influence of the seagrass, Zostera 417 marina, on current flow. Estuarine Coastal and Shelf Science 15, 351-364.

418 Fonseca, M.S., Koehl, M.A.R., 2006. Flow in seagrass canopies: the influence of patch width. 419 Estuarine Coastal and Shelf Science 67, 1-9.

420 Gacia, E., Duarte, C.M., 2001. Sediment retention by a Mediterranean Posidonia oceanica 421 meadow: the balance between deposition and resuspension. Estuarine Coastal and Shelf $422 \quad$ Science 52, 505-514.

423 Green, M.O., 2011. Very small waves and associated sediment resuspension on an estuarine $424 \quad$ intertidal flat. Estuarine Coastal and Shelf Science 93, 449-459. 
425 Grizzle, R.E., Greene, J.K., Luckenbach, M.W., Coen, L.D., 2006. A new in situ method for

426 measuring seston uptake by suspension-feeding bivalve molluscs. Journal of Shellfish

$427 \quad$ Research 25, 643-649.

428 Grizzle, R.E., Greene, J.K., Coen, L.D., 2008. Seston removal by natural and constructed

429 intertidal eastern oyster (Crassostrea virginica) reefs: a comparison with previous laboratory

$430 \quad$ studies, and the value of in situ methods. Estuaries and Coasts 31, 1208-1220.

431 Hasegawa, N., Hori, M., Mukai, H., 2008. Seasonal changes in eelgrass functions: current

432 velocity reduction, prevention of sediment resuspension, and control of sediment-water

433 column nutrient flux in relation to eelgrass dynamics. Hydrobiologia 596, 387-399.

434 Herman, P.M.J., Middleburg, J.J., Widdows, J., Lucas, C.H., Heip, C.H.R., 2000. Stable isotopes

435 as trophic tracers: combining field sampling and manipulative labeling of food resources for

436 macrobenthos. Marine Ecology Progress Series 204, 79-92.

437 Houser, C., Trimble, S., Morales, B., 2015. Influence of blade flexibility on the drag coefficient

438 of aquatic vegetation. Estuaries and Coasts 38, 569-577.

439 Judge, M.L., Coen, L.D., Heck, K.L., 1993. Does Mercenaria mercenaria encounter elevated

440 food levels in seagrass beds? Results from a novel technique to collect suspended food

441 resources. Marine Ecology Progress Series 92, 141-150.

442 Kang, C.K., Kim, J.B., Lee, K.S., Kim, J.B., Lee, P.Y., Hong, J.S., 2003. Trophic importance of

443 benthic microalgae to macrozoobenthos in coastal bay systems in Korea: dual stable $\mathrm{C}$ and $\mathrm{N}$

444 isotope analyses. Marine Ecology Progress Series 259, 79-92.

445 Kenworthy, W.J., Zieman, J.C., Thayer, G.W., 1982. Evidence for the influence of seagrasses on

446 the benthic nitrogen cycle in a coastal plain estuary near Beaufort, North Carolina (U.S.A.).

$447 \quad$ Oecologica 54, 152-158.

448 Kobayashi, M., Hofmann, E., Powell, E.N., Klinck, J., Kusaka, K., 1997. A population dynamics

449 model for the Japanese oyster, Crassostrea gigas. Aquaculture 149, 285-321. 
450 Koch, E.W., Ackerman, J.D., Verduin, J., van Keulen, M., 2006. Fluid dynamics in seagrass

451 ecology - from molecules to ecosystems. Pages 193-225 in Larkum, A.W.D., Orth, R.J., 452 Duarte, C.M. (eds) Seagrasses: Biology, Ecology and Conservation. Springer, New York

453 Koch, E.W., 2001. Beyond light: physical, geological, and geochemical parameters as possible

454 submerged aquatic vegetation habitat requirements. Estuaries 24, 1-17.

455 Koch, E.W., Gust, G., 1999. Water flow in tide- and wave-dominated beds of the seagrass

456 Thalassia testudinum. Marine Ecology Progress Series 184, 63-72.

457 Lebreton, B., Richard, P., Galois, R., Radenac, G., Pfléger, C., Guillou, G., Mornet, F., Blanchard,

458 G., 2011. Trophic importance of diatoms in an intertidal Zostera noltii seagrass bed: evidence 459 from stable isotope and fatty acid analysis. Estuarine Coastal and Shelf Science 92, 140-153.

460 Luhar, M., Rominger, J., Nepf, H., 2008. Interaction between flow, transport and vegetation 461 spatial structure. Environmental Fluid Mechanics 8, 423-439.

462 Madsen, J.D., Chambers, P.A., James, W.F., Koch, E.W., Westlake, D.F., 2001. The interaction 463 between water movement, sediment dynamics and submersed macrophytes. Hydrobiologia $464 \quad 444,71-84$.

465 Moore, K.A., 2004. Influence of seagrasses on water quality in shallow regions of the lower 466 Chesapeake Bay. Journal of Coastal Research 45, 162-178.

467 Nelson, T.A., Waaland, J.R., 1997. Seasonality of eelgrass, epiphyte, and grazer biomass and 468 productivity in subtidal eelgrass meadows subjected to moderate tidal amplitude. Aquatic $469 \quad$ Botany 56, 51-74.

470 Newell, R.I.E., Koch, E.W., 2004. Modeling seagrass density and distribution in response to 471 changes in turbidity stemming from bivalve filtration and seagrass sediment stabilization. $472 \quad$ Estuaries 27, 793-806.

473 Peterson C.H., Black R., 1987. Resource depletion by active suspension feeders on tidal flats: 474 Influence of local density and tidal elevation. Limnology and Oceanography 32, 143-166. 
475 Pinheiro, J., Bates, D., DebRoy, S., Sarkar, D. and R Core Team, 2016. nlme: Linear and

476 Nonlinear Mixed Effects Models. R package version 3.1-128, http://CRAN.R-

$477 \quad$ project.org/package $=$ nlme.

478 Plutchak, R., Major, K., Cebrian, J., Foster, C.D., Miller, M.C., Anton, A., Sheehan, K.L., Heck,

479 K.L., Powers, S.P., 2010. Impacts of oyster reef restoration on primary productivity and

480 nutrient dynamics in tidal creeks of the north central Gulf of Mexico. Estuaries and Coasts 33,

$481 \quad 1355-1364$

482 Porter, E.T., Mason, R.P., Sanford, L.P., 2013. Effects of shear stress and hard clams on seston,

483 microphytobenthos, and nitrogen dynamics in mesocosms with tidal resuspension. Marine

$484 \quad$ Ecology Progress Series 479, 25-45.

485 R Core Team, 2015. R: A Language and Environment for Statistical Computing. R Foundation

486 for Statistical Computing, Vienna, Austria

487 Ralph, P.J., Durako, M.J., Enriquez, S., Collier, C.J., Doblin, M.A., 2007. Impact of light

488 limitation on seagrasses. Journal of Experimental Marine Biology and Ecology 350, 176-193.

489 Ren, J.S., Ross, A.H., 2001. A dynamic energy budget model of the Pacific oyster Crassostrea

$490 \quad$ gigas. Ecological Modelling 142, 105-120.

491 Richardson, N.F., Ruesink, J.L., Naeem, S., Hacker, S.D., Tallis, H.M., Dumbauld, B.R.,

492 Wisehart, L.M., 2008. Bacterial abundance and aerobic microbial activity across natural and

493 oyster aquaculture habitats during summer conditions in a northeastern Pacific estuary.

$494 \quad$ Hydrobiologia 596, 269-278.

495 Ruesink, J.L., 2016. Epiphyte load and seagrass performance are decoupled in an estuary with

496 low eutrophication risk. Journal of Experimental Marine Biology and Ecology 481, 1-8.

497 Ruesink, J., 2018. Data from: Comparison of shallow water seston among biogenic habitats

498 (eelgrass, oysters, bare) on tidal flats. Mendeley Data, v2

499 http://dx.doi.org/10.17632/9y8xrhvhmy.1 
500 van Oevelen, D., Soetart, K., Middelburg, J.J., Herman, P.M.J., Moodley, L., Hamels, I., Moens, 501 T., Heip, C.H.R., 2006. Carbon flows through a benthic food web: Integrating biomass, 502 isotope and tracer data. Journal of Marine Research 64, 453-482.

503 Walles, B., Salvador de Paiva, J., van Prooijen, B.C., Ysebaert, T., Smaal, A.C., 2015. The 504 ecosystem engineer Crassostrea gigas affects tidal flat morphology beyond the boundary of 505 their reef structure. Estuaries and Coasts 38, 941-950.

506 Welschmeyer, N., 1994. Fluorometric analysis of chlorophyll-a in the presence of chlorophyll-b 507 and phaeopigments. Limnology and Oceanography 39:1985-1992

508 Wheat, E.E., Ruesink, J.L., 2013. Commercially-cultured oysters (Crassostrea gigas) exert top509 down control on intertidal pelagic resources in Willapa Bay, Washington, USA. Journal of Sea Research 81, 33-39.

Widdows, J., Pope, N.D., Brinsley, M.D., Asmus, H., Asmus, R.M., 2008. Effects of seagrass beds (Zostera noltii and Z. marina) on near-bed hydrodynamics and sediment resuspension.

514 Wilkie, L., O’Hare, M.T., Davidson, I., Dudley, B., Paterson, D.M., 2012. Particle trapping and 515 retention by Zostera noltii: A flume and field study. Aquatic Botany 102, 15-22.

516 Worcester, S.E., 1995. Effects of eelgrass beds on advection and turbulent mixing in low current 517 and low shoot density environments. Marine Ecology Progress Series 126, 223-232.

518 Yang, S. Wheat, E.E., Horwith, M.J., Ruesink, J.L., 2013. Relative impacts of natural stressors on 519 life history traits underlying resilience of intertidal eelgrass (Zostera marina L.). Estuaries $520 \quad$ and Coasts 36, 1006-1013.

521 Zuur, A.F., Ieno, E.N., Walker, J.N., Saveliev, A.A., Smith, G.M., 2009. Mixed effects models and 522 extensions in ecology with R. Springer, New York. 
Figure $\mathbf{1}$ (on next page)

Biogenic species across study sites.

(A) Study sites in Washington State, USA. (B) Dry above-ground biomass of eelgrass (Zostera marina) in three habitat patches per site. (C) Estimated dry meat weight of oysters (Crassostrea gigas) from length-frequency distribution in three habitat patches per site. Error bars show SE of 10 quadrats per patch. 
A) Site locations

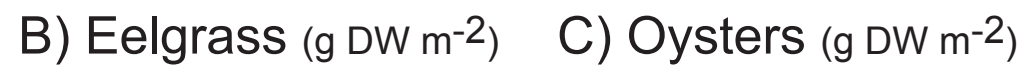

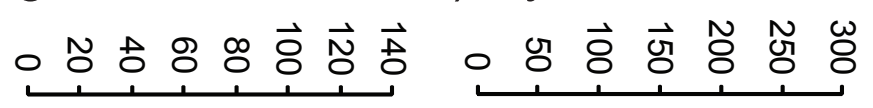

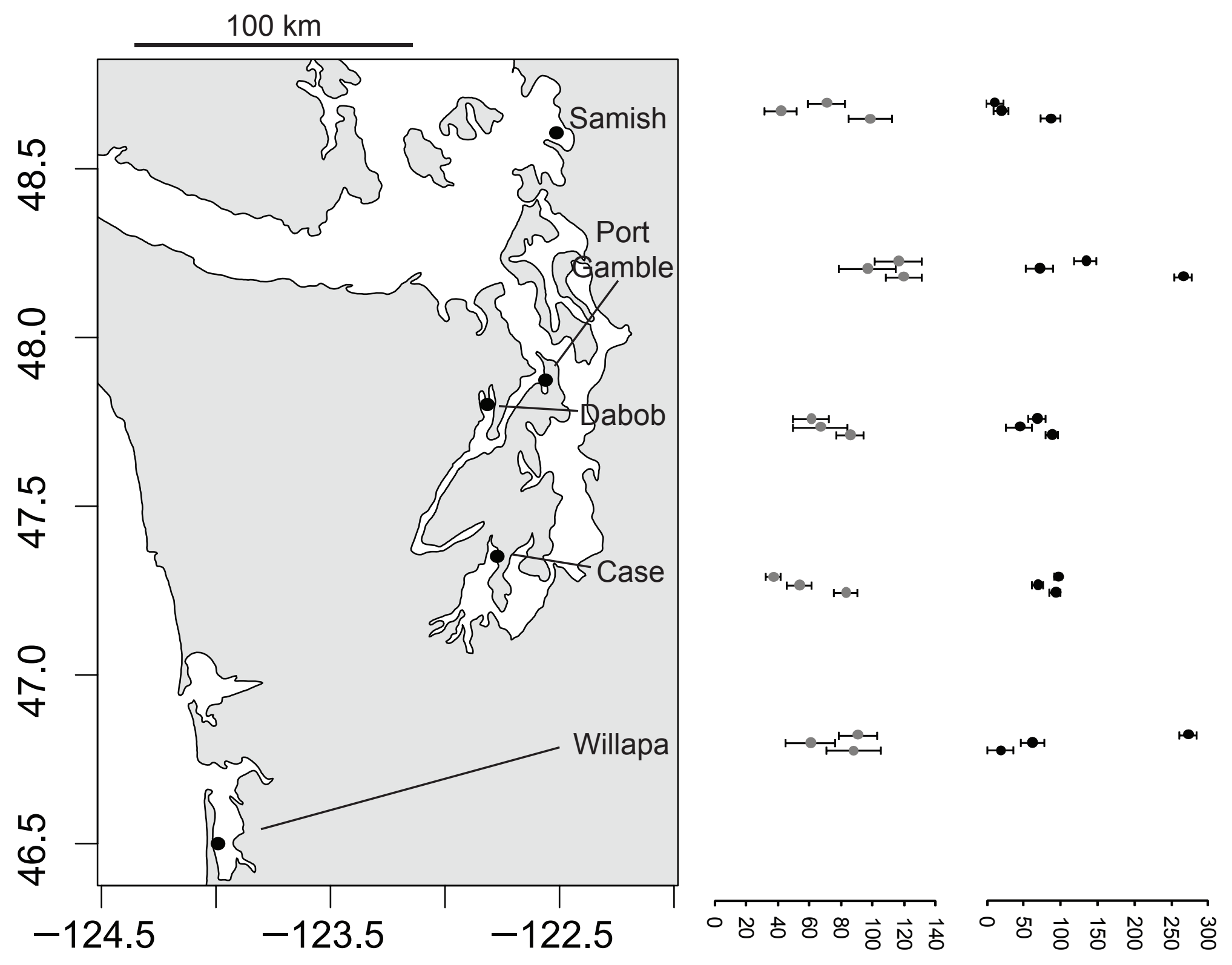




\section{Figure 2}

Neutrally buoyant Lagrangian drifter (diameter $0.8 \mathrm{~m}$ ), with GPS unit at center

Photo credit: Micah Horwith

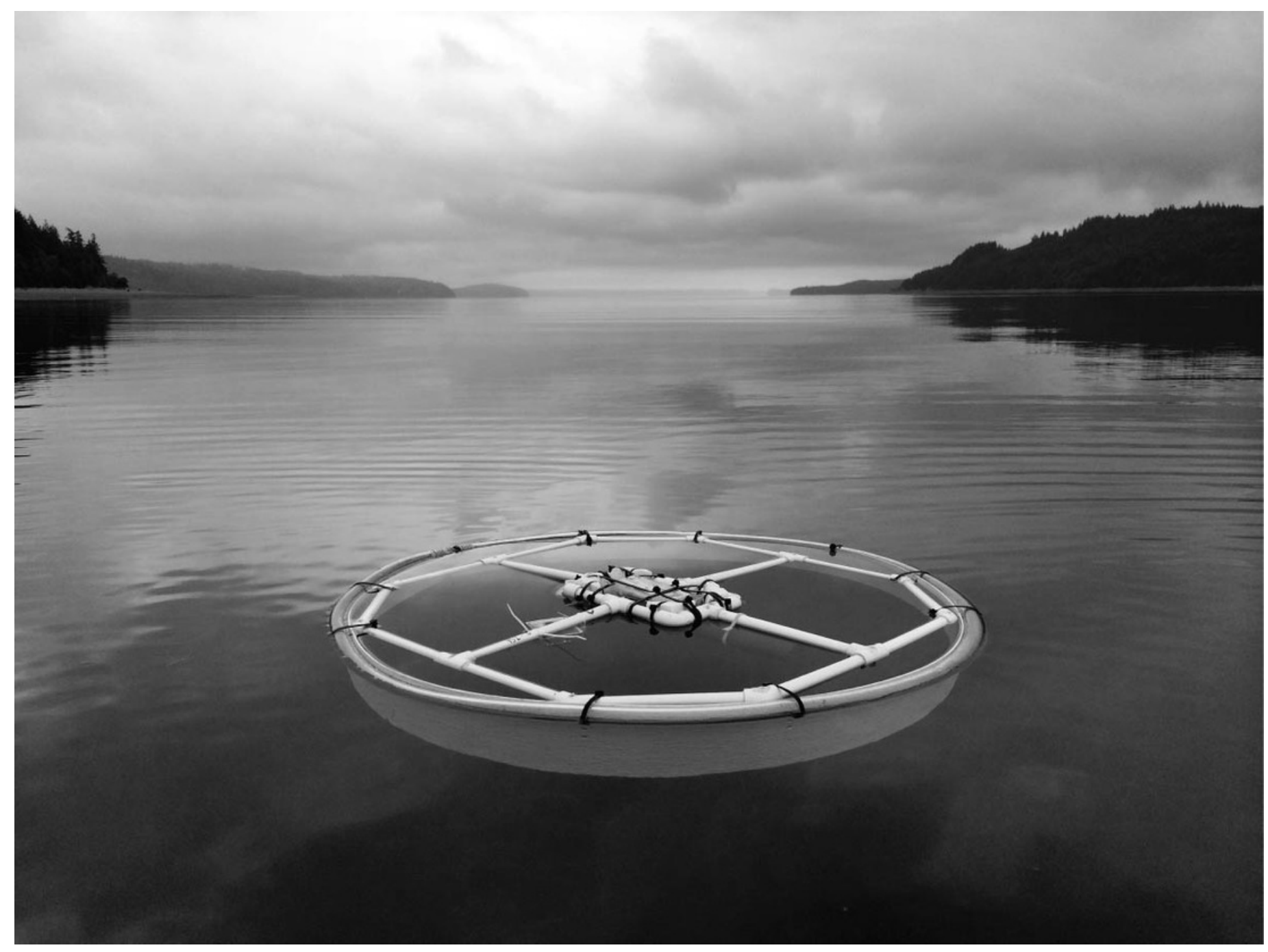


Figure 3 (on next page)

Characteristics of 135 drifts in shallow water across a mosaic of habitat types occupying intertidal flats in Washington State, USA

Each point refers to one patch, with mean and standard errors calculated from the three drifts across that patch. (A) Distance from the start to end of each drift, demonstrating the dimension of each habitat patch. (B) Surface water velocity during drifts. (C) Duration of drifts. 

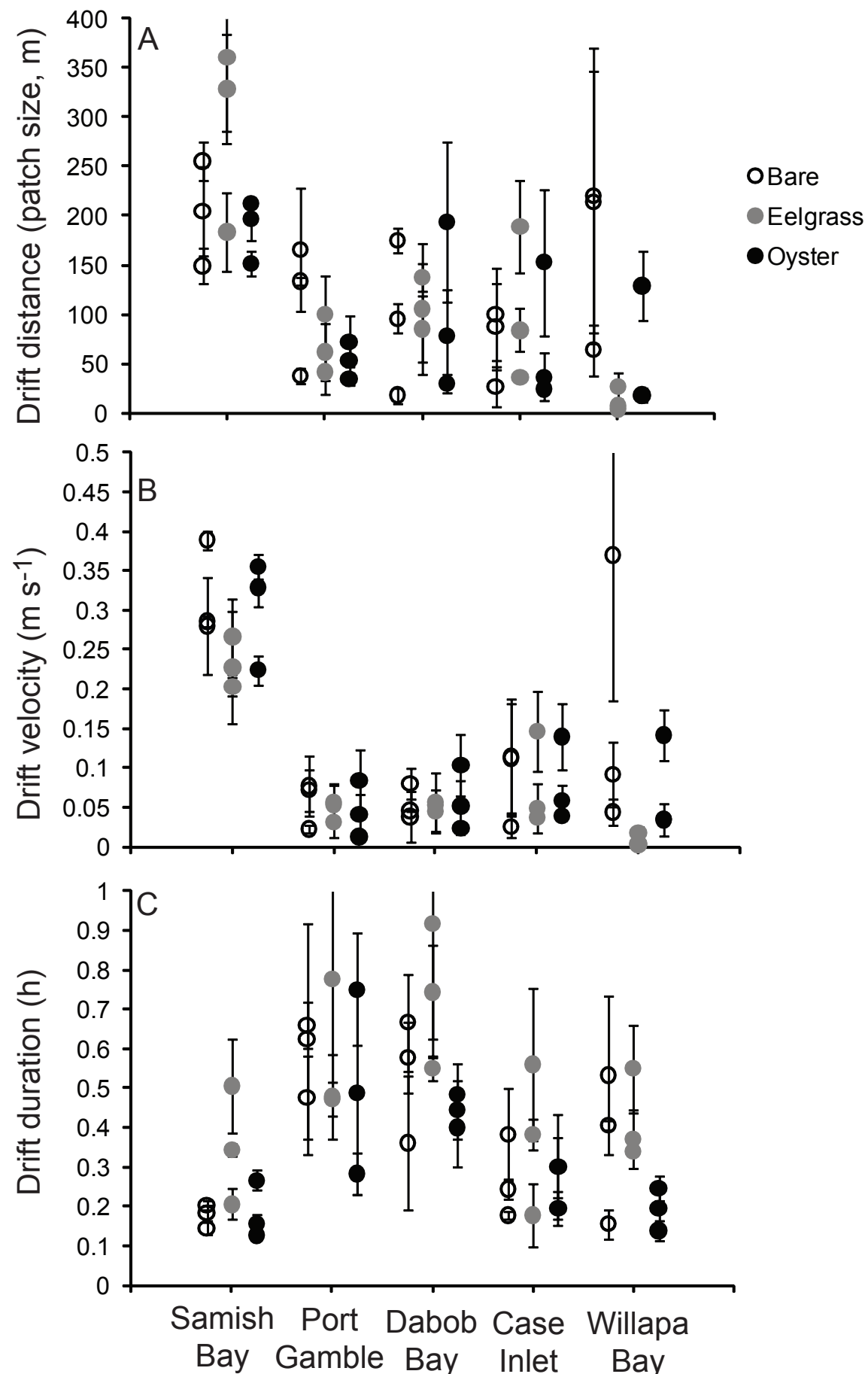
Figure 4(on next page)

Water properties at the initiation of each drift when water was at different depths over three intertidal habitat types at five sites in Washington State, USA.

(A) Total suspended solids. (B) Chlorophyll-a. Lines are plotted from the coefficients of linear mixed effects models including factors significant at $\alpha<0.05$. 


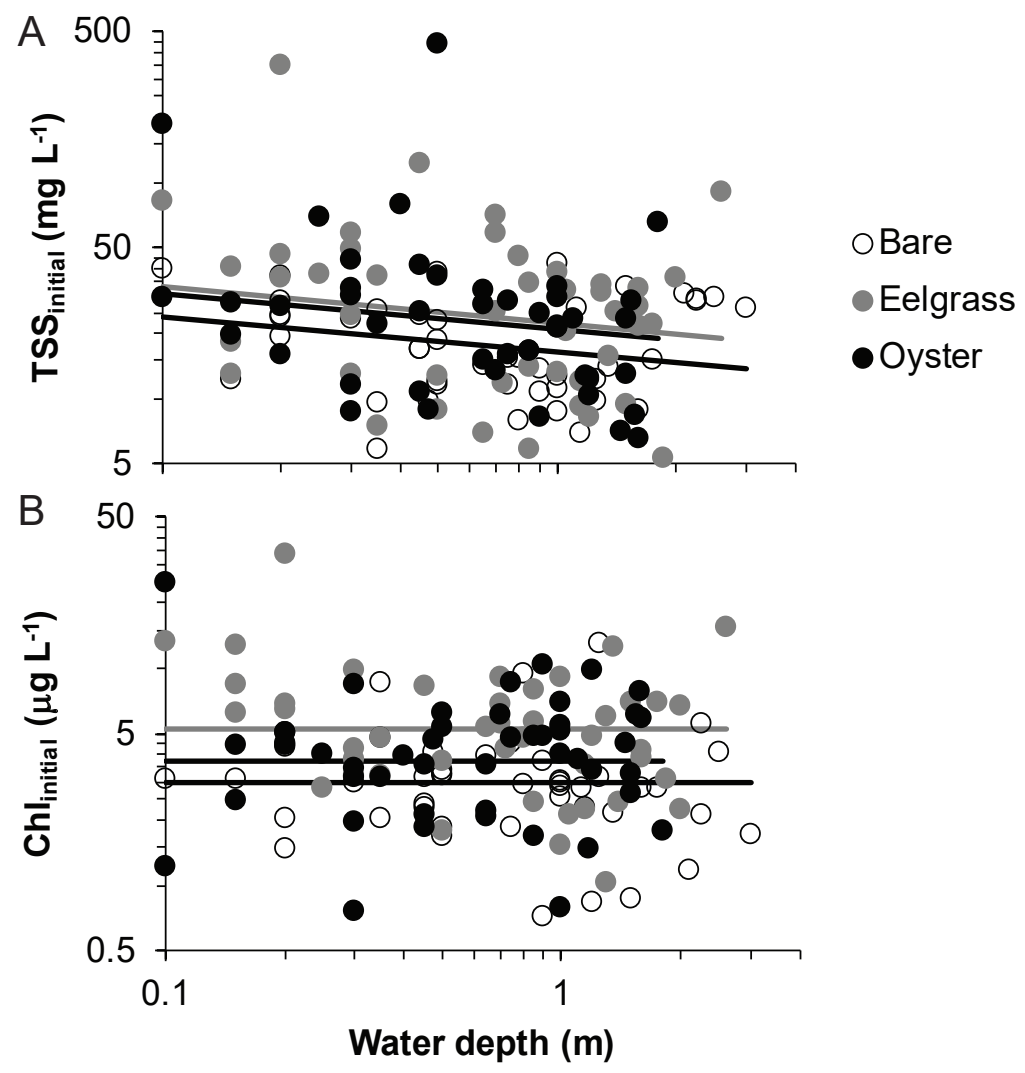


Figure $\mathbf{5}$ (on next page)

Change in water properties during drifts when water was at different depths over three intertidal habitat types at five sites in Washington State, USA.

(A) Change in total suspended solids, based on the log-ratio. (B) Change in chlorophyll-a, based on the log-ratio. Lines are plotted from the coefficients of linear mixed effects models including factors significant at $\alpha<0.05$; habitat was not significant in these models, so a single relationship is shown. 

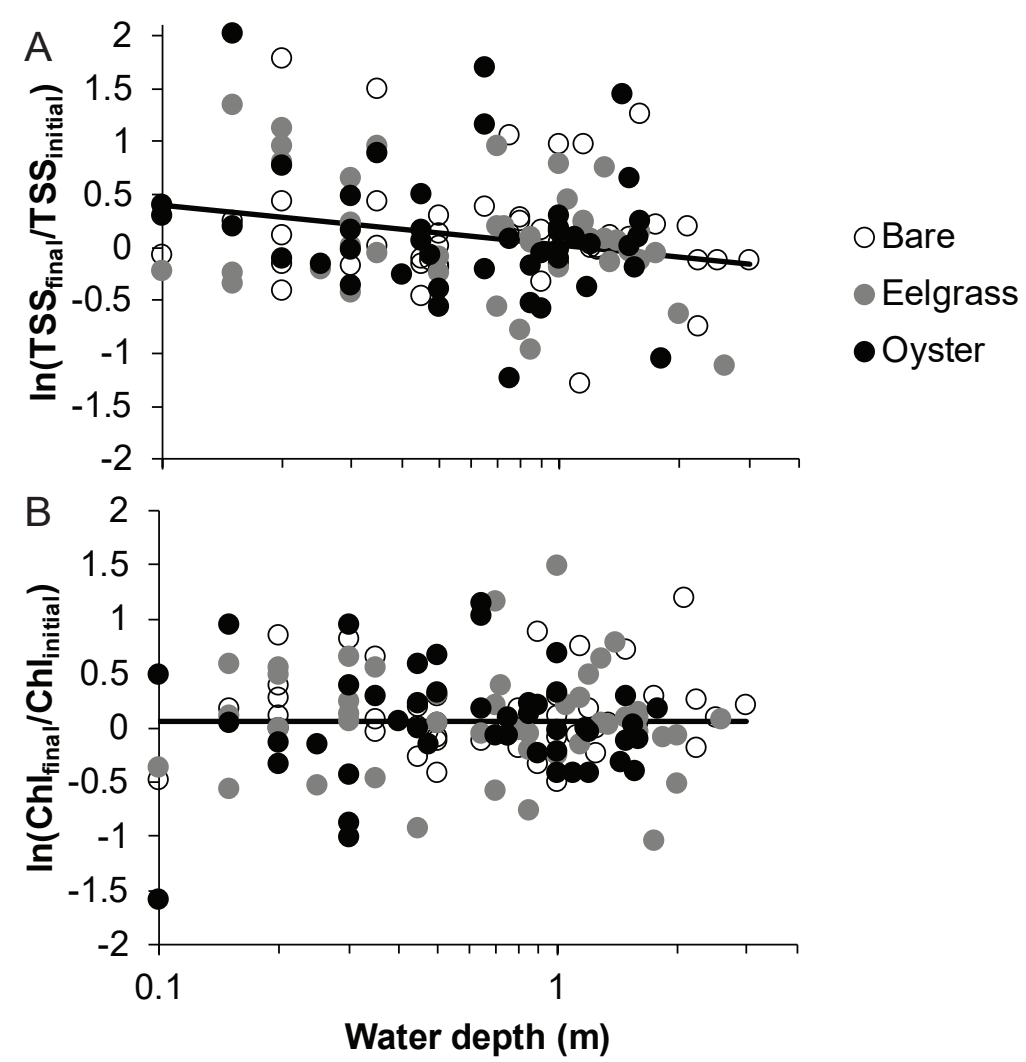


\section{Figure 6 (on next page)}

Water velocity during drifts when water was at different depths over three intertidal habitat types at five sites in Washington State, USA.

Lines are plotted from the coefficients of a linear mixed effects model including factors significant at $\alpha<0.05$. Although the residuals in this plot appear to violate assumptions of normal distributions, the distributions were suitable for analysis in the linear mixed effects model, which accounted for site and subsite as random effects. 


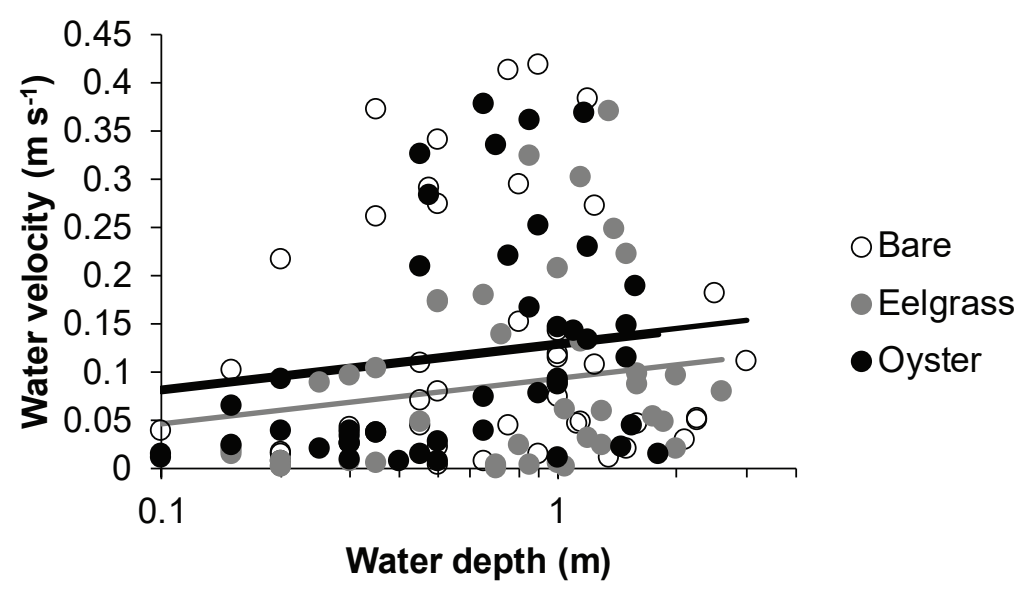


Figure 7 (on next page)

Quality of seston in shallow water during drifts over three intertidal habitat types at five sites in Washington State, USA.

(A) Organic content, and (B) Chlorophyll-a concentration in water varying in total suspended solids. Samples include both initial and final measurements for each drift. Lines are plotted from coefficients of linear mixed effects models including factors significant at $a<0.05$. Accordingly, a single relationship is shown for proportion organic, where habitat was not significant, but separate lines for chlorophyll-a due to water over eelgrass containing higher concentrations than over bare. 


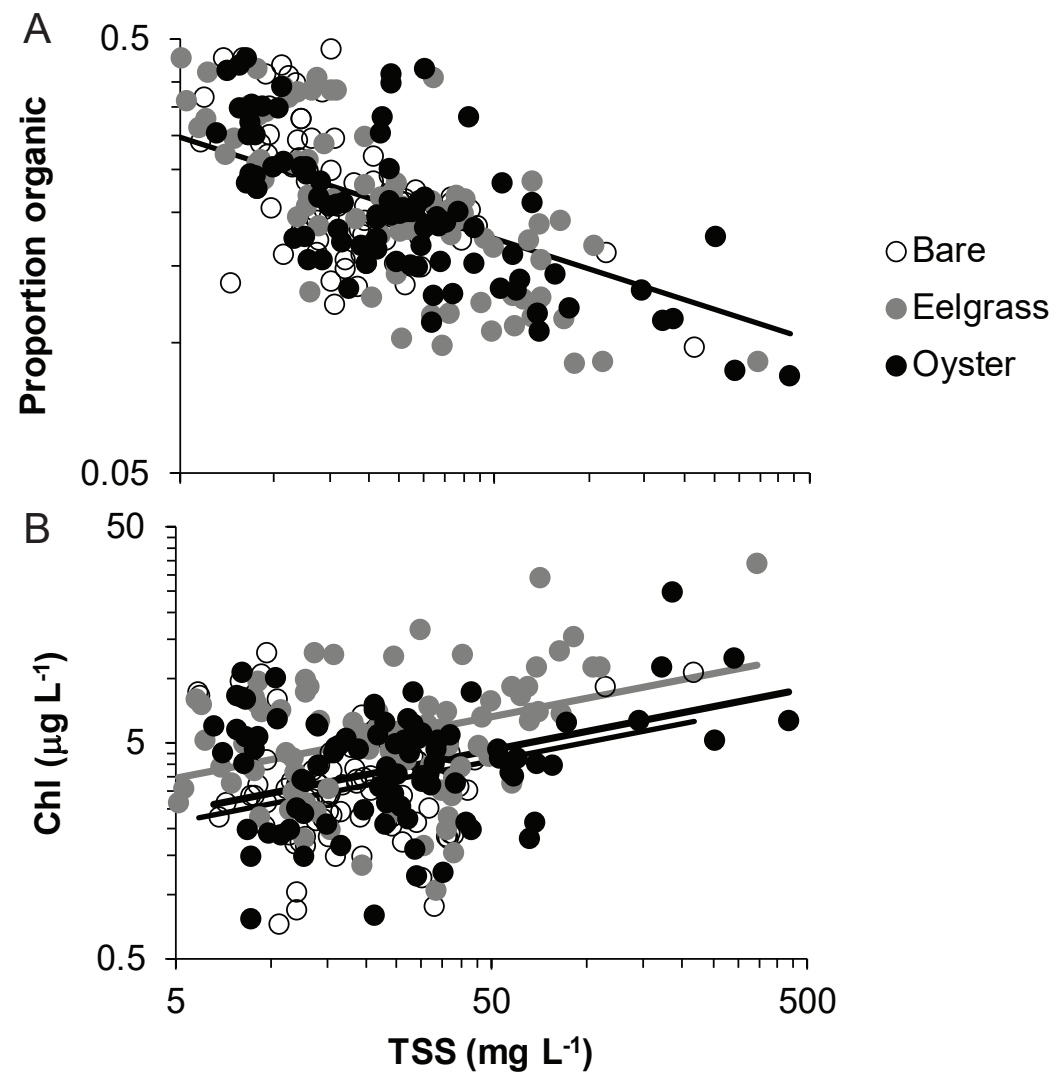




\section{Table $\mathbf{1}$ (on next page)}

Results of linear mixed effects models of water properties during each drift at five sites in Washington State, USA, in summer 2014

Each column presents one of five water properties. Each row provides $F$ value ( $P$ value) for main effects of habitat and depth, for their interaction, and for planned contrasts between biogenic habitats (eelgrass, oyster) and bare when habitat was significant. Random effects were site, and subsite in site. TSS = total suspended solids, $\mathrm{mg} \mathrm{L}^{-1}$. Chl = chlorophyll-a, $\mu \mathrm{g} \mathrm{L}^{-1}$. Samples were not used in analysis of TSS unless $0<$ proportion organic $<0.5$. Some samples were not available for calculation of water velocity due to GPS malfunction. 


\begin{tabular}{|c|c|c|c|c|c|}
\hline \multicolumn{6}{|c|}{ Response } \\
\hline & $\ln \left(\mathrm{TSS}_{\text {initial }}\right)$ & $\ln \left(\mathrm{Chl}_{\text {initial }}\right)$ & Water & $\ln \left(\mathrm{TSS}_{\text {final }} / \mathrm{TSS}_{\text {initial }}\right)$ & $\ln \left(\mathrm{Chl}_{\text {final }} / \mathrm{Chl}_{\text {initial }}\right)$ \\
\hline & $n=132$ & $n=136$ & velocity & $n=127$ & $n=136$ \\
\hline & & & \multicolumn{3}{|l|}{$n=130$} \\
\hline \multirow[t]{2}{*}{ Habitat } & $4.56(0.013)$ & 14.9 & 4.97 & $0.02(0.98)$ & $0.42(0.66)$ \\
\hline & & $(<0.0001)$ & $(0.009)$ & & \\
\hline \multirow[t]{2}{*}{$\ln ($ Depth$)$} & $8.14(0.005)$ & $3.61(0.06)$ & 9.20 & $7.58(0.007)$ & $0.41(0.52)$ \\
\hline & & & $(0.003)$ & & \\
\hline Habitat x & $0.56(0.57)$ & $0.70(0.50)$ & $0.88(0.42)$ & $0.07(0.93)$ & $0.17(0.84)$ \\
\hline \multicolumn{6}{|l|}{$\ln ($ Depth $)$} \\
\hline Bare vs. & $E>B$ & $E>B$ & $\mathrm{E}<\mathrm{B}$ & & \\
\hline Eelgrass & $\mathrm{P}=0.003$ & $\mathrm{P}<0.0001$ & $\mathrm{P}=0.009$ & & \\
\hline Bare vs. & $\mathrm{O}>\mathrm{B}$ & $\mathrm{O}>\mathrm{B}$ & $\mathrm{O}=\mathrm{B}$ & & \\
\hline Oyster & $\mathrm{P}=0.013$ & $\mathrm{P}=0.019$ & $\mathrm{P}=0.47$ & & \\
\hline
\end{tabular}

1 


\section{Table 2 (on next page)}

Results of linear mixed effects models of water properties using initial and final samples for each drift at five sites in Washington State, USA, in summer 2014

Each column contains a distinct water property: chlorophyll-a (Chl), and proportion organic. Each row provides $F$ value ( $P$ value) for main effects of habitat and total suspended solids (TSS), for their interaction, and for planned contrasts between biogenic habitats (eelgrass, oyster) and bare when habitat was significant. Random effects were site, and subsite in site. Samples were not used in analysis unless $0<$ proportion organic $<0.5$. The interaction effect (habitat $x \ln (T S S)$ ) was close to $P=0.05$ in this mixed effects model, therefore interpreted cautiously. 


\begin{tabular}{lll}
\hline & Response & \\
\hline & $\ln (\mathrm{Chl}) \mathrm{n}=261$ & $\mathrm{ln}($ proportion organic) \\
& & $\mathrm{n}=262$ \\
\hline Habitat & $24.2(<0.0001)$ & $0.10(0.90)$ \\
$\ln (\mathrm{TSS})$ & $57.3(<0.0001)$ & $146.1(<0.0001)$ \\
Habitat $\mathrm{l} \ln (\mathrm{TSS})$ & $3.16(0.044)$ & $0.49(0.61)$ \\
\hline Bare vs. Eelgrass & $\mathrm{E}>\mathrm{B} \mathrm{P}<0.0001$ & \\
Bare vs. Oyster & $\mathrm{O}=\mathrm{B} \mathrm{P}=0.03$ & \\
\hline
\end{tabular}

1 